\title{
Public participation in post-communist cities between stagnation and progress: The examples of Zagreb and Ljubljana
}

Public participation in the urban transformation of capital cities is an important factor to consider when assessing the quality of democracy in post-communist countries. This study examines participatory processes in two capital cities, Zagreb (Croatia) and Ljubljana (Slovenia). The cases studied are summarized, and similarities and differences are pointed out using the comparative method (Tabor Park and the BS 7 neighbourhood in Ljubljana, and the Meštrović Pavilion and Savica Park in Zagreb). Findings from 2018 and 2019 showed a rather low level of public participation in Zagreb. In Ljubljana, the lev- el of public participation was higher and the legal basis for it stronger, although there was a certain amount of dependence on political and economic factors. In both cities, public participation in its most direct form was present at the level of NGO and civil initiative activities. Residents' communication with the city administration was poor and did not facilitate the participation process.

Keywords: participation process, civil society initiatives, comparative method, Zagreb, Ljubljana 


\section{Introduction}

In the former Yugoslavia, which both Croatia and Slovenia were part of, spatial management was conditioned by the socio-political context, and it was largely based on planning and state control. Social, economic, and spatial development issues were addressed comprehensively within the social planning system (Slovenian: sistem družbenega planiranja, Burton et al. 1967; Croatian: društveni plan, Čaldarović \& Kritovac, 1987). In the post-communist period, the state's role in spatial management ceased. The focus shifted to the privatization of space and real estate, land reuse and redevelopment, and redefinition of the roles of planning institutions (Bertaud and Renaud, 1997; Golubchikov, 2004; Dimitrovska Andrews et al., 2007; Hirt, 2012; Sýkora \& Stanilov, 2014; Svirčić Gotovac \& Kerbler, 2019; Zlatar Gamberožić, 2019). However, the market-oriented economy revealed a lack of common interest and vision in urban planning. Instead, a certain laissez-faire approach or economic liberalism was embraced in urban planning and public policies, which created (and continues to create) uneven urban development and economic inequality (Offe, 1997; Jaakson, 2000; Nikšič \& Sezer, 2017). As a result, attractive city locations have become large building sites, profits on various investments have soared, and less-attractive locations have stagnated (Nikšič, 2014; Patti \& Polyak, 2017). "The tyranny of the state" has been replaced by "the tyranny of the market” (Häussermann \& Kapphan, 2004: 26), which is the beginning of the commercialization process of urban space. In the situation in which the main activities of urban development have shifted from planned improvements across the city to economically driven interventions in certain favourable locations, the role of the public in the development process must be addressed. This article first defines the public participation process as part of the decision-making process in spatial and urban planning in the post-communist context. It uses the cases of two post-communist capital cities, Zagreb and Ljubljana.

In the post-communist city, market demands and private interests are much more relevant than planning as a process. Even public investments are focused on the sectors and projects that can improve the attractiveness of the city for profit rather than improve the general quality of life for its residents (Stanilov, 2007; Sykora, 2007; Patti \& Polyak, 2017). The urban planning transition from communism to post-communism has been marked by neglect of the social dimension of urban living and housing, and of strategic and long-term urban planning. The market economy characteristics present since the $1990 \mathrm{~s}$ (privatization, reduction of public space, and the global financial system) influence the relations among the stakeholders in the urban planning processes; specifically, their roles and pow- ers. Western countries use terms such as high levels of citizen participation, high legal standards, and successful public-private partnerships. In urban planning, the countries of the former Yugoslavia are struggling with limitations in the legal system and insufficient public participation in the decision-making processes. However, the reasons for the rather slow transition in most parts of the former Yugoslavia certainly lie in the conflict of the 1990s and the break with and isolation from European and global trends (Beyea et al., 2009). The transition process was faster in the ex-communist countries that started EU accession activities earlier, such as Slovenia.

The transition process in Slovenia has been rather smooth in comparison with the rest of the former Yugoslavia due to some initial advantages: Slovenia fought a brief war of independence, and it joined the EU relatively quickly and immediately adopted its urban planning programmes. EU funding also soon became available and provided for a number of urban projects that were initiated and supported by city political and administrative structures (Zlatar Gamberožić, 2019). Croatia saw many spatial transformations emerge after declaring independence and strengthening of the privatization process in the 1990s, and the involvement of the market economy in spatial development.

In Croatia, the planning process is primarily determined by the Master Plan (Croatian: generalni urbanisticki plan) at the level of urban centres (Zagreb and other cities), the Spatial Development Strategy and Spatial Planning Programme of the Republic of Croatia, and the Spatial Plan of the City of Zagreb. According to the plan, in the process of planning and plan implementation there is an obligation to adopt urban development plans, conduct public tenders, prepare studies, and allow public participation (Master Plan, Articles 99-108). Public tender is obligatory for public spaces (squares and parks), and the Master Plan allows the development of city projects and determines the procedure for implementing them. The Master Plan and its amendments and supplements are sent to the $\mathrm{Za}$ greb City Assembly for adoption. Participation of the public is provided by holding exhibitions and preliminary discussions on spatial plans, and by providing public access to draft spatial plans and the results of public tenders (Grad Zagreb, 2016).

According to the Spatial Planning Act (Sln. Zakon o urejanju prostora, 2017; hereinafter: ZUreP-2), the authority for spatial planning in Slovenia is held at the national and local (municipal) levels. The hierarchy of spatial planning acts is divided into strategic documents and implementation acts. The strategic documents define the main direction of future development and its main principles, and the implementation acts are locality-specific and are legally binding. Public participation in preparing the strategic plans is more often in the form of public 
consultations, but more active forms of public involvement are required for preparing and adopting the implementation acts; among other things, the public participation process has to be decided in the form of a public participation plan (Slovenian: načrt vključevanja javnosti) in the preparation phases (ZUrep-2, 2017; ESPON, 2018).

\section{The participation process as part of the urban planning process}

As described in Arnstein's Ladder of Citizen Participation (Arnstein, 1969, Figure 1), public participation in urban planning can vary from the lowest level of participation (manipulation) to the highest (control). At the lowest levels (nonparticipation) and the first phase, not only do people have no influence on decision-making, but they are manipulated into believing that everything is done in their best interest. The proposed plan is the best, and the task of participation is to achieve public support through public relations. In the second phase of passive participation (tokenism), they receive information about urban projects as they happen, without any possibility of intervening. Only placation allows members of the public to advise or plan ad infinitum, but it retains the right for power holders to judge the legitimacy or feasibility of the advice. Under citizen control (partnership and delegation), power is redistributed through negotiation between the public and power holders. The highest level and the final phase of participation implies that residents can initiate urban projects and thus design their own living space with no intermediaries or source of funds. At this level they can control urban policy and be an equal member of the entire planning process.

Many authors later followed Arnstein's scheme. For example, Anokye (2013) also describes various paths to participation: the higher level is the transformative approach, and the lower one is the instrumental approach, and there is also a combination between the two of them. The transformative approach is equivalent to Arnstein's citizen control and the instrumental approach is the equivalent of her nonparticipation. Most participation systems are in the mixed model, implying that residents know about or have occasionally participated in some kind of consultations, and they are in a certain way informed about the decisions that city authorities will implement. Nevertheless, this does not mean that they have really participated in the process and that they will be empowered to change political decisions. This approach is therefore instrumental in a way, employing methods that involve top-down information flows and not strengthening the actors (Anokye, 2013: 82). This approach still does not involve agreement, nor consensus, with a potential conflict constantly present between the sides involved. According to Hordijk et al. (2015), this approach

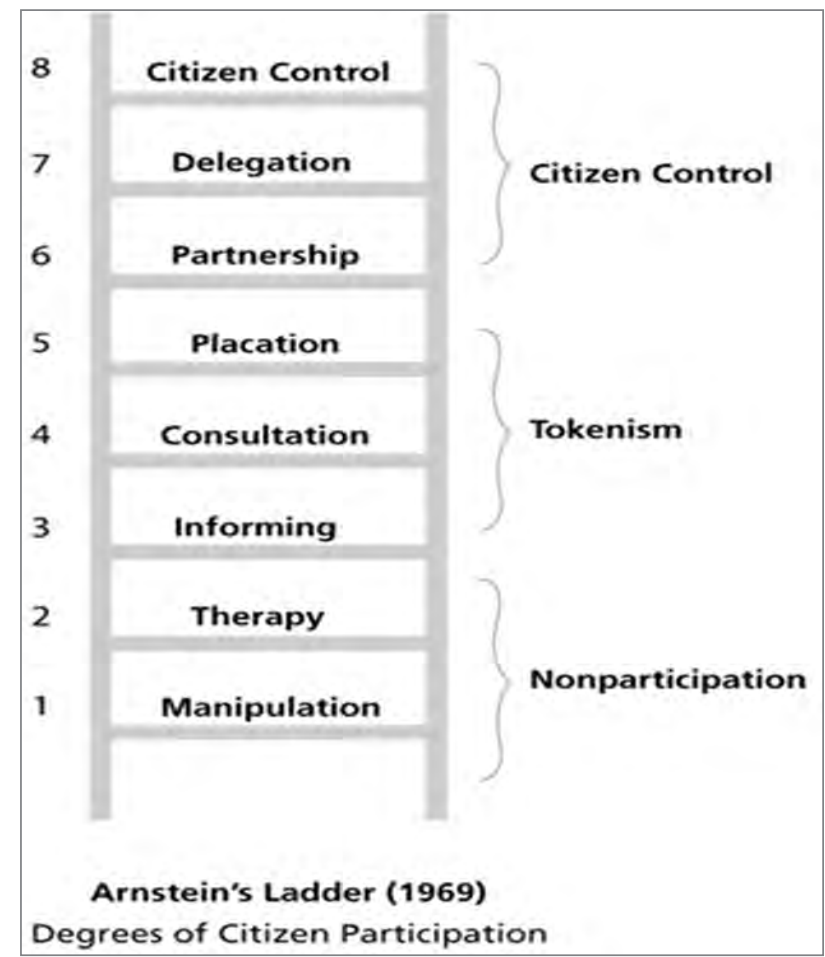

Figure 1: Arnstein's Ladder of Citizen Participation (source: Internet 1).

is related to the diminished roles of the state and its citizens, referring to them as clients or consumers that cannot influence the process of making decisions but can only adhere to them because they are unchangeable. The transformative approach uses bottom-up communication and represents a higher level of participation, in which stronger public involvement can be expected.

\subsection{Participation in Zagreb}

Although Croatia joined the EU in 2013 and has strived to adapt its legal system to that of the $\mathrm{EU}$, and although a number of bills have been introduced seeking better cohesion, decentralisation, horizontal governance, and increasing importance of the participation process in urban development, not much of this can be found in practice. Hence, under Croatian law, public participation has been reduced to public access to draft spatial plans, which can last from thirty days to only fifteen days (to suggest changes and amendments).

During public consultation, members of the public have the right to participate in the process of drawing up and passing spatial plans and to offer their proposals or comments. This is a top-down model of participation in which spatial changes are decided by the government and only minor issues raised by residents are considered (e.g., a private plot of land within the planning zone). The public has very little influence on changes in spatial plans, and ultimately on the conversion of space, most 
often public space. Public interest is declared to be important and valuable, but collaboration with the public is formal or lacking, and its proposals are not necessarily accepted. In the last few decades, city authorities have often started projects that were rejected by the public and have resulted in the shrinkage of public space. It is interesting that, regardless of EU accession, the Master Plan for Zagreb has not fundamentally changed since 2007 and has been modified for years depending on market needs (of economic and political actors). There has been a lack of professional and political collaboration, and non-governmental organizations (NGOs) and various civil initiatives, which have flourished during recent decades as a civil society sector, have taken a stand in defence of public interest. When city streets and squares were subjected to unwanted or inadequate renewal, protests and large-scale demonstrations were held to prevent such changes. However, the authorities have rarely given up on their projects and have managed to see them through. Still, the NGO sector has become an important actor in public participation that is striving to establish communication between political forces and the public, and involve residents in the process so that they can express their interests. Despite its undoubtedly greater visibility, Bežovan and Zrinščak (2006: 8) emphasize that "civil society is still more reactive than proactive, and civil society organizations still do not appear as specific 'generators' of social capital."

There are some legal options for people to present their proposals or complain (at local public meetings). A decision made at a local public meeting is mandatory for the local committee council or city district council, but it is not binding for the city assembly (Internet 2, Articles 127-129), which is an example of how the public can be excluded from the procedure and how residents' voices are not taken into account in the final phases of projects. Such an approach can be connected with the instrumental approach mentioned above, which is related to the reduced role of the state and the general public, who is therefore very passive. It can also be connected with Arnstein and the lower participation ladder - that is, non-participation (informing, therapy, and manipulation). It could also explain why residents express a certain degree of unwillingness to take part in the participatory process. Currently, some aspects of local self-government are not encouraging for residents; they are aware of their limitations, irrelevance, and marginality when it comes to solving problems of daily life in a community (Rešetar, 2009; Toš, 2012). In this one-way process, there is frequent manipulation with certain conversions of space and strengthening of political power, especially the role of the mayor's office. It is interesting that the mayor gives an impression in public discourse of an actor interested in improving people's quality of life and meeting their desires and needs; however, due to collaboration with investors, such endeavours are never carried out. Only the dominant elites participate in the deci- sion-making process as the chosen and more influential part of the population, thus leading to "elite capture", which distorts the advancement of participation (Silver et al., 2010) or the involvement of the majority of residents.

\subsection{Participation in Ljubljana}

The formal basis for public participation in environmental and spatial development processes is the Aarhus Convention (UNECE, 1998), which was ratified by Slovenia in 2004, the year that it joined the EU, and after this it was integrated into national legislation, including ZUrep-2 (2017; hereinafter: the Act). The principle of public participation is defined in Article 11 of the Act. It provides that the competent authorities should facilitate early and effective participation by the public in decision-making and adoption of spatial planning documents, and in spatial planning matters in general. Everyone should be given the right of access to spatial planning documents and all documentation related to their preparation and adoption in accordance with the Act and the law governing access to public information. Everyone has the right to submit initiatives, proposals, comments, and opinions on spatial planning documents, to which the body must position itself in their preparation and inform the public thereof. The Act also foresees a special legal status for non-governmental organizations (NGOs) that are active in the public interest in spatial planning, environmental protection, nature conservation, or the protection of cultural heritage; their legal interest in spatial development is considered manifest by the Act itself. In addition, Article 85 of the Act requires establishing a public participation plan for preparing spatial documentation. Article 111 additionally defines the procedures for producing local or municipal plans and it foresees public consultations, workshops, or other means of public engagement.

However, Kvac et al. (2015) point out that one of the main obstacles for the full implementation of participatory practices is a passive, formal-only implementation of the demands for participatory approaches as defined by legislation. The comments and ideas from the public that are collected during public consultations are rarely taken into serious consideration by planning authorities, no matter how well they are argued. The procedures defined by the law are also not fully supportive of participatory practices; for example, when institutions make major changes to the initial publicly discussed plan, the final plan may be considerably different but it does not go into public hearings and discussions once more. Therefore, the civil initiative groups and non-governmental organizations push the participatory practices in spatial planning further through their own bottom-up activities (Nikšič et al., 2018). In addition to such concrete activities, they also work on capacity building, providing recommendations and instructions that 
encourage the authorities at the local level of spatial planning to include the public in the spatial planning processes and, on the other hand, guide the people on how to be proactive and raise their voice within rather complicated procedures. These documents are an important "soft" tool that guides stakeholders through complex processes by showcasing the most appropriate tools and techniques to be used.

When the City of Ljubljana started preparing its new (first post-communist) spatial plan twenty years ago (Mestna občina Ljubljana, 2002), the city authorities understood the need for a truly participatory approach to obtain a well-considered and consensual plan that would reflect the aspirations of the widest range of local stakeholders. Numerous expert studies were carried out, consultations with various interest groups were conducted, and thematic workshops with residents were held in addition to the legally binding procedures that demanded the inclusion of the general public in the planning process. This resulted in a number of publications and documents that reflected the aspirations and ideas of the general public that would not have been revealed without the extensive use of the participatory tools. The results of these extensive participatory activities did not, however, always find their way into the legally binding planning documentation and were therefore only partly successful because the political situation in the city changed. The new authorities that came into power in 2006 had their own development visions, which were explicitly topdown driven and not always in accordance with the objectives identified in the initial (participatory) stage (Koželj, 2009). The current local government, however, fully implements the legally binding formal steps of public consultation (e.g., every time the amendments and the additions to the spatial plan are made). Nevertheless, participation in its most direct form is still happening at the level of grassroots activities. Groups of self-organized residents are active in various neighbourhoods of Ljubljana, and their activities are largely based on volunteer work and enthusiasm because they receive very little support from public budgets (Nikšič, 2018; Internet 3). Two such initiatives (Tabor Park and the BS 7 neighbourhood) are described in this article.

\section{Methods}

This article is based on the results of the bilateral project Urban Revitalization of the City Centre: A Comparison between Ljubljana and Zagreb (2018-2019). The comparative method was applied to study urban revitalization in the two cities, examining their similarities, common characteristics, and differences (Žugaj et al., 2006). Field research was conducted in 2018 and 2019 in Zagreb and Ljubljana on four case studies, two in Zagreb and two in Ljubljana. As Burnham et al.
(2008) point out, the comparative method makes it possible to put information into a context to be assessed and interpreted, which is especially important when new information appears and needs to be connected with previous knowledge. An attempt was also made to show a binary comparison between two similar countries that are most often part of the same regional context (Dogan, 2009: 23); in this case, Croatia and Slovenia. The comparative method in the social sciences permits a more objective understanding of a social phenomenon, its contextualization and classification, and formulation of conclusions (hypothesis testing) and predictions (Hague et al., 2001; Reason \& Bradbury, 2001). According to Denzin and Linkoln (1994), case studies provide a deeper understanding of social processes by analysing a case or several cases. They represent an empirical inquiry that investigates a contemporary phenomenon within its real-life context and relies on multiple sources of evidence. Case studies as concrete examples can offer an in-depth and contextualized understanding of a certain phenomenon (Ritchie \& Lewis, 2003; Yin, 2003).

The aim of the research was to present differences in the participation process through the selected cases and through the comparative method to define concrete and problematic moments in establishing and implementing public participation. The aims of the research can be summed up at several levels of comparison: 1) How did the public and the civil sector react and how did they activate themselves? 2) Was there a change in the preliminary project plan due to the intervention or reaction of the civil sector? and 3) Which participation model according to Arnstein and other authors was applied in the case of Ljubljana, and which in the case of Zagreb (instrumental, transformative, or combined)? The comparative analysis examined each case separately through the chronology of events from the beginning of each project through the involvement and activation of the public to the final result: the reaction or, in some cases, action of civil actors. The comparison between the cases took place at two levels: a) a comparison of two cases in each country separately, and b) a comparison of all four cases in Slovenia and Croatia with an emphasis on participatory models, examining the role of civil actors in each case to show participatory models for each country. The four examples studied (Tabor Park and the BS 7 neighbourhood in Ljubljana, and the Meštrović Pavilion and Savica Park in Zagreb) were selected because they represent the participation process of various interested sides (professional, political, and civil circles) in both cities. They are the most vivid and prominent examples of the differences between these two countries in the top-down versus bottom-up planning processes. These models are related to the hypotheses on the instrumental, transformative, and combined approaches (Anokye, 2013) in the participation process, according to which the cases analysed can be positioned. 


\section{Results}

\subsection{First example of bottom-up participation: Tabor Park in Ljubljana}

Tabor Park (Sln. Park Tabor) is a local park in the east part of the city, which can be reached in a ten-minute walk from Prešeren Square, the main square in Ljubljana. The Tabor Sports Society grounds are part of this open area, which measures about 1.2 hectares. Although it is the green centre of a wider neighbourhood, it has been neglected and abandoned for many years, and people were reluctant to linger at night because of bad maintenance and poor lighting. In 2010 Prostorož, a cultural association seeking to improve urban public space and public participation, decided to explore the potential of the space (Internet 3). One of the missions was to encourage local residents to actively participate in the planning and implementation phases of the park redesign, using minimum financial means and making small-scale improvements to the space in order to encourage socializing, playing, and working out in the open air and pleasant environment. Based on research on the potential and problems of the area (Cerar \& Peterlin, 2010) and a series of participatory workshops, a programme of various activities was set up and carried out from 2010 to 2014. The aims of the activities were threefold: to introduce small spatial improvements to make the place welcoming and enjoyable, to change the traffic regime and prioritize non-motorized traffic, and to create opportunities for locals and visitors to socialize. Prostorož coordinated the activities of volunteer organizations, decided on the outdoor park equipment, and made plans for the changed traffic regime.

Although Tabor Park (Figure 2) is a representative case of a bottom-up approach, it was also given some basic financial support by the local authorities, which at least allowed the cultural association to operate its coordinating activities. The municipal departments were cooperative and flexible enough to issue the necessary permits. The collaboration between Prostorož and the municipal departments had the potential for setting up similar participatory practices in other parts of the city. This would be an important step toward revitalization of similar suburban public spaces without large investments (Bugarič, 2018). Along the way, those involved with Tabor Park obtained better insight into the structure and operational mechanisms of the municipal departments and indicated there was still room for improvement in terms of participatory practice. No matter how well-meaning their suggestions might have been, once publicly expressed they were often interpreted as criticism of the city authorities, which resulted in withdrawal of support not only for the specific project but also for other activities by the initiators (Human Cities Archives, 2017).

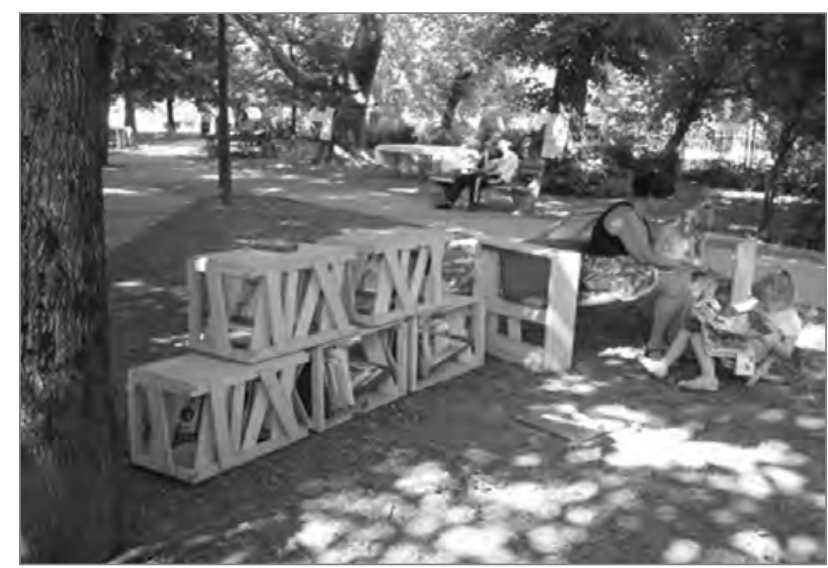

Figure 2: Tabor Park in May 2011: various activities in the park (photo: Matej Nikšič).

\subsubsection{The BS 7 neighbourhood in Ljubljana}

Another interesting case study with important lessons to learn is the BS 7 neighbourhood (Sln. soseska BS 7) on the northern outskirts of Ljubljana, known also as the Russian Tsar neighbourhood (Sln. soseska Ruski car). This is one of the largest housing developments in the Slovenian capital, built in the 1970s with a large open central area named Bratovž Square (Sln. Bratovševa plošcad). In the communist period this was a place for socializing, but today it is a rather underused transitory area. It is in physically bad shape due to the effects of age on the building materials and insufficient maintenance in the past decades. Because of its unclear ownership (in addition to being a central open public space, it also accommodates private underground parking facilities), no renewal has started. A group of local residents (the initiative Skupaj na plošcad! 'Together onto the Square!') (Figure 3) have therefore started some new activities to show the great potential that the place holds and thus hopefully encourage all owners (of underground parking facilities, of the nearby blocks of flats, and the municipality) to agree and invest in its redesign. Each year the initiative voluntarily organizes various activities for and with the local residents to bring life into the neighbourhood, such as a street cinema, vegetable markets, or street furniture workshops. The area and public participation have attracted the international attention of the Human Cities activities within the EU's Creative Europe programme (Franc et al. 2018), which aims to empower local residents in their bottom-up activities through experimental use of various participation tools. From 2014 to 2018, many on-site events were held, such as neighbourhood walks, roundtables, neighbourhood picnics, drawing and model-making workshops, interviews, online photo competitions, and street exhibitions to encourage the locals not only to start socializing in the square, but to join forces and decide together about the comprehensive regeneration of the place (Nikšic et al., 2018). Even when the city administration eventually 


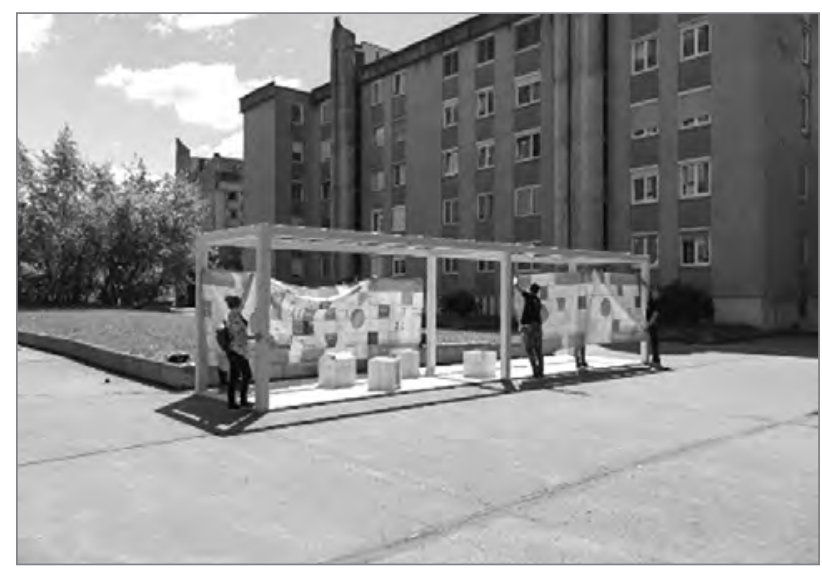

Figure 3: Participatory activities in the underused public space in the BS 7 neighbourhood (photo: Tomaž Zupan).

recognized the importance of the project and offered financial support for it, disagreement in the local community about the project costs and the future design of the place blocked the regeneration endeavours. This case shows that, even when there is a wide support (among the residents, the municipality, and local and international expertise), the inability of all stakeholders to find a common language can prevent the best-intended participatory endeavours from bearing fruit. However, such activities are an important contribution in terms of capacity building for participatory urban (re)development, which can only start when the major players have reached an agreement on the fair share of investment costs.

\subsection{A top-down or reactionist activism approach to the participatory process in Zagreb: The Meštrović Pavilion}

The renovation of the Meštrović Pavilion (Cro. Mestrovićev paviljon; Figure 4) in the middle of Victims of Fascism Square (Cro. Trg žrtava fasizma) in central Zagreb was announced as the first stage of the project named the Pedestrian Centre of Excellence. The pavilion is an example of a cultural and artistic monument and a public space favoured by the residents, because of which they monitored the intervention intensively. The case study analysis from 2018 and 2019 showed that residents' reaction was negative and they tried to stop the project. At the very beginning, the area around the pavilion were stripped of all its greenery in order to proceed with the planned renewal. The strongest protest was staged by local residents and others after a magnolia tree was removed, leaving the space bare and sterile, far from meeting human needs. The campaign Bring Back the Magnolia Tree (Cro. Vratite magnoliju) was launched, which lasted for six months. Because the entire project was poorly presented to the public, regular procedures were violated or sidestepped, and experts

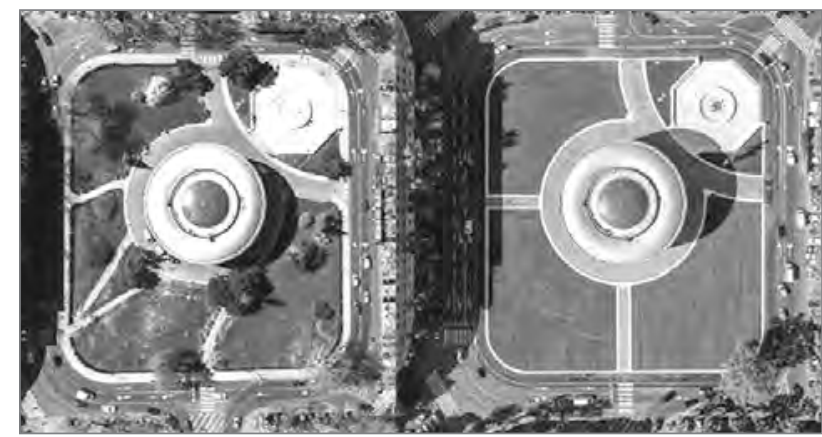

Figure 4: The Meštrović Pavilion before and after the renovation in 2017 and in 2018 (source: Dobrić, 2018).

from broader professional and independent circles, who were attempting to influence the project implementation with their knowledge, were ignored. The initiative demanded suspension of the work, public consultation, protection of plant life, the return of the magnolia tree, and a more constructive discussion prior to finalizing the project. They sent their requests and appeals to city and state government institutions. In spite of all these activities and the growing resistance by civil initiative groups, there was no reaction from the authorities and the first stage of the project was completed.

The planning stage included the installation of new horticultural drainage, the replacement of damaged stairs encircling the pavilion, laying new granite paving slabs and stone curbs, and new benches, garbage bins, public bicycle racks. However, without a public tender and consultation, the project appeared to be the result of the mayor's autocratic rule and manipulative methods that prevented the community and relevant professionals from participating in decision-making. Protected cultural heritage and its historical identity was also altered and modified without much consideration. In the end, something good came out of this urban renewal attempt. The initiative Bring Back the Magnolia Tree made the authorities promise to never again do things the way they were done in this square (Svirčić Gotovac \& Zlatar Gamberožić, 2020). This case clearly shows that, in matters of shrinking public and green space in Zagreb, non-governmental organizations have become the only mediator between the residents and the government and the only response to arbitrary governmental action.

\subsubsection{Savica Park in Zagreb}

The case of Savica Park (Cro. Park Savica; 2013-2018) was about building a church in a local park. The local parish submitted a request for the location permit, but none of the owners of the adjacent land were notified about this. Under unclear circumstances, a non-existing "road" was entered in the cadastre between the building site and a neighbouring build- 


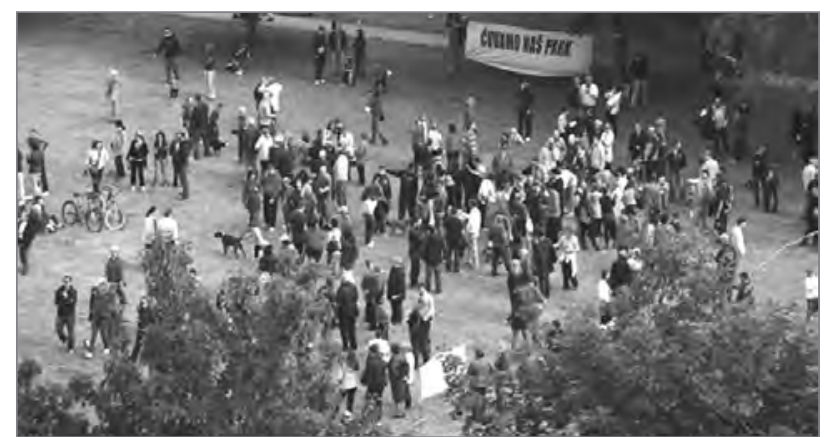

Figure 5: Protest against building a church in Savica Park in 2017 (source: HINA, 2016).

ing. The local residents thereby lost the right to complain and then decided to launch the campaign Save Our Park (Cro. Cuvamo naš park; Figure 5), which lasted for five years. It was organized primarily because the tendering procedures were non-transparent and the entire project would reduce the park area. The church building was to take up 1,600 square metres, almost one-third of the total park area. The people that joined the initiative constantly emphasized they were not against the church building but against the location selected. The residents involved in collecting the signatures to support the initiative called themselves "residents that approve of the church but not in our park". They sent letters to the relevant city offices and the mayor himself, following all procedures. The Society of Architects and the Croatian Association of Landscape Architects sided with the public and opposed the project. Finally, the Ministry of Construction and Spatial Planning revoked the permit issued by the City of Zagreb in 2016. The reasons cited, among others, were the size of the project, which was not in line with the Master Plan, and the absence of public tender procedures.

The examples of the Meštrović Pavilion and Savica Park are similar in their early stages and the public reaction to them. The cases differ, however, at a later stage, when the location permit was revoked for the latter project after several years of civil actions. However, these cases show that civil initiative groups joined by the professionals can become powerful enough to stop arbitrary behaviour in politics. Nonetheless, this is not exactly the way in which civil actors are expected to take part in participatory practices, but it is a way to raise public awareness and make them active.

\section{Discussion}

The comparative analysis of the Meštrović Pavilion and Savica Park in Zagreb showed that both projects had two things in common: neglect of public and expert opinion, and the city administrative bodies' steady efforts to see the initial plans through in spite of a number of unclear or incomplete legal procedures. The residents opposed the projects by launching various more or less successful initiatives. The case of Ljubljana highlights the importance of active citizenship, which means proactive residents being able and willing to contribute to rethinking and redesigning their living environment. On the other hand, it clearly shows the volatility of the participatory practices and their dependence on the (non)support of the political and financial powers - as long as the support exists, the cooperation between the bottom-up and top-down endeavours will more likely result in a win-win situation. In order to achieve this, in addition to the legally binding participatory framework, trust, cooperation, and dialogue among all relevant partners are needed. Tabor Park showed to a great extent the fruitful cooperation among the local actors, whereas the BS 7 neighbourhood case demonstrated that the participatory approach may have a limited range if there are too many tensions among different actors.

Public participation in urban planning and the renewal and protection of public space still remains relatively low, as can be seen from the examples of Zagreb and Ljubljana. Likewise, cities in southern Europe experience low satisfaction with city streets or buildings (Emerson \& Smiley, 2018: 166), which can be related to the reduced participation shown here and the reduced impact of the public in public spaces. In Zagreb, public involvement is reduced to protests against specific urban projects and can be called reactionist activism, which in these cases also turns into the status quo situation or the passive acceptance of a given situation. In Ljubljana, local communities form much more equal partnerships with local authorities when decisions are made about their daily life and environment. All the actors concerned also show a great deal of dedication to their respective tasks. Rethinking the role and influence of the local community is vitally important in post-communist urban planning (Hlaváček et al., 2016). The public participation process should be strengthened to allow people to fully take part in decisions about their immediate environment.

\section{Conclusion}

In comparison with Zagreb, the Ljubljana examples show higher levels of public participation and a better community-led planning process (Svirčić Gotovac \& Kerbler, 2019). This is especially true in the case of Tabor Park, where civil initiative groups and local residents worked together with the city administration in organizing street events in the park and making it a pleasant place for people to socialize. The grassroots activities in Ljubljana are also more proactive compared to mainly reactive practices in Zagreb - instead of protesting against the top-down imposed spatial interventions, the civil initiatives in Ljubljana mainly work on enhancing the poten- 
tial of certain urban environments and promoting cooperation between different stakeholders. This means that the example of Ljubljana has shown deflection from the post-communist one-way instrumental model and has reached the transformative level, whereas Zagreb has remained at the instrumental level. The mixed model can also occasionally be observed in the example of Savica Park in Zagreb because the residents stopped the building of a church, demanding greater participation and that their needs be taken into account, and so their civil action can also fall within the transformative approach. Nevertheless, because it was not a two-way process, it is primarily an example of instrumental participation.

However, the Ljubljana model can be even more successful once it receives stronger political support, which is currently rather weak and unstable. The local authorities still remain reluctant to fully accept grassroots movements as equal partners in the participatory process, and they may still perceive their well-intended criticism as a threat. The same threat seems to be a problem in Zagreb, where true participation never occurs, but it is only present in the form of a response to an already existing situation, and where communication with the authorities is clearly insufficient. The research hypothesis about Ljubljana having higher levels of public participation in matters of life and environmental quality than Zagreb has thus been confirmed. Still, there is much room for improvement in both cities because of the inability of local actors (experts, residents, and authorities) to find a common language and act together, which remains an ongoing challenge for the participatory process. This calls for changes in the legislative framework, educating the public about its rights, and opening up to new bottom-up practices in accordance with the EU recommendations to ensure that public participation remains a constant in the spatial planning process and that urban policy responds to public needs.

Anđelina Svirčić Gotovac, Institute for Social Research in Zagreb, Zagreb, Croatia

E-mail: angelinasg@gmail.com

Jelena Zlatar Gamberožić, Institute for Social Research in Zagreb, Zagreb, Croatia

E-mail: zlatar.jel@gmail.com

Matej Nikšič, Urban Planning Institute of the Republic of Slovenia, Ljubljana, Slovenia

E-mail: matej.niksic@uirs.si

\section{Acknowledgment}

This article presents the research results of the bilateral project The Urban Revitalization Process in Ljubljana's City Centre (in Comparison with Zagreb's City Centre) conducted by the Institute for Social Research in Zagreb and the Urban Planning Institute of the Republic of Slovenia. The project was financed by the Croatian Ministry of Sci- ence and Education and the Slovenian Research Agency (ARRS). The article was created with the help of the ARRS research core funding no. P5-0100.

\section{References}

Anokye, N. A. (2013) Stakeholder participation in water resources management: The case of Densu Basin in Ghana. Doctoral thesis. Amsterdam, Vrije Universiteit.

Arnstein, S. R. (1969) A ladder of citizen participation. Journal of the American Institute of Planners, 35(4), pp. 216-224. DOI: 10.1080/01944366908977225

Bertaud, A. \& Renaud, B. (1997) Socialist cities without land markets. Journal of Urban Economics, 41(1), pp. 137-151. DOI: 10.1006/juec.1996.1097

Beyea, W., Geith, C. \& McKeown, C. (2008) Place making through participatory planning. Chapter 4. In: Foth, M. (ed.) Handbook of research on urban informatics: The practice and promise of the real-time city, pp. 5568. Hershey, PA, Information Science Reference.

DOI: $10.1093 / \mathrm{cdj} / 35.1 .41$

Bežovan, G. \& Zrinščak, S. (2006) Is civil society in Croatia becoming a force for social change? Croatian Journal of Social Policy, 14(1), pp. 1-27.

Botes, L. \& van Rensburg, D. (2000) Community participation in development: Nine plagues and twelve commandments. Community Development Journal, 35, pp. 41-58. DOI: 10.1093/cdj/35.1.41

Bugarič, B. (2018) Urban acupuncture treatment: Implementing communication tools with youth in Ljubljana suburbs. Urbani izziv, 29(Special edition), pp. 95-108.

DOI: 10.5379/urbani-izziv-en-2018-29-supplement-006

Burnham, P., Gilland, K., Grant, W. \& Layton-Henry, Z. (2008) Research methods in politics. London, Macmillan. DOI: 10.1007/978-0-230-36556-8

Burton, R., Dickman, W. \& Fisher, J. C. (1967) Toward a system of social planning in Yugoslavia. Papers of the Regional Science Association, 18, pp. 75-86. DOI: 10.1007/BF01940313

Čaldarović, O. \& Kritovac, F. (1987) Stambene potrebe i njihovo zadovoljavanje. In: Bežovan, G. \& Kuzmanović, M. (eds.) Stambena politika i stambene potrebe, pp. 63-80. Zagreb, Radničke novine.

Cerar, A. \& Peterlin, M. (eds.) (2010) Revitalizacija parka Tabor: urejanje parka z vključevanjem lokalne skupnosti. Ljubljana, IPOP.

Denzin, N. K. \& Linkoln, Y. S. (eds.) (1994) Handbook of qualitative research. Thousand Oaks, CA, Sage Publications.

Dimitrovska Andrews, K., Mihelič, B. \& Stanič, I. (2007) The post-socialist urban restructuring of Ljubljana: Strengthening identity. In: Stanilov, K. (ed.) The post-socialist city: Urban form and space transformations in Central and Eastern Europe after socialism, pp. 427-447. Cincinnati, $\mathrm{OH}$, Springer. DOI: 10.1007/978-1-4020-6053-3_21

Dobrić Žaja, S. (2018) Kreće li Bandićev napad na Branimirac i Krešimirac? Available at: https://www.h-alter.org/vijesti/krece-li-bandicev-napad-nabranimirac-i-kresimirac (accessed 1 Sept. 2020).

Dogan, M. (2009) Strategies in comparative sociology. In: Sasaki, M. (ed.) New frontiers in comparative sociology. International studies in sociology and social anthropology, pp. 13-45. Leiden, Brill.

Emerson, M. O. \& Smiley, K. T. (2018) Across cities. In: Emerson, O. \& Smiley, K. T. (eds.) Market cities, people cities. The shape of our urban future, pp. 162-177. New York, New York University Press. DOI: $10.18574 /$ nyu/9781479856794.003.0008 
ESPON (2018) COMPASS - Comparative Analysis of Territorial Governance and Spatial Planning Systems in Europe. Luxembourg, ESPON.

Franc, J., Peyricot, O., Ermacora, T. \& van Hasselt, F. (eds.) (2018) Human cities challenging the city scale: journeys in people-centred design. Basel, Birkhäuser Verlag.

Golubchikov, O. (2004) Urban planning in Russia: Towards the market. European Planning Studies, 12(2), pp. 229-247.

DOI: $10.1080 / 0965431042000183950$

Grad Zagreb (2016) Odluka o donošenju Generalnoga urbanističkog plana grada Zagreba (pročišćeni tekst). Available at: https://www.zagreb.hr/ odluka-o-donosenju-generalnoga-urbanistickog-plana/89158 (accessed 25 Feb. 2021)

Häusserman, H. \& Kapphan, A. (2004) Berlin: from divided into fragmented city. The Greek Review of Social Research, 113, pp. 25-61. DOI: $10.12681 /$ grsr.9216

HINA (2016) Park na Savici: izdana lokacijska dozvola za gradnju crkve bl. Alojzija Stepinca. Available at: https://www.nacional.hr/park-na-savici-izdana-lokacijska-dozvola-za-gradnju-crkve-bl-alojzija-stepinca/ (accessed 1 Sept. 2020).

Hirt, A. S. (2012) Iron curtains gates, suburbs and privatization of space in the post-socialist city. Hoboken, NJ, John Wiley \& Sons. DOI: 10.1002/9781118295922

Hlaváček, P., Raška, P. \& Balej, M. (2016) Regeneration projects in central and eastern European post-communist cities: Current trends and community needs. Habitat International, 56, pp. 31-41.

DOI: 10.1016/j.habitatint.2016.04.001

Hordijk M., Miranda Sara L., Sutherland C. \& Scott D. (2015) Participatory instruments and practices in urban governance. In: Gupta, J., Pfeffer, K., Verrest, H. \& Ros-Tonen, M. (eds.) Geographies of Urban Governance, 26(1), pp. 130-146. DOI: 10.1007/978-3-319-21272-2_7

Human Cities Archives (2017) Interviews with initiators of civil initiatives. Unpublished materials of the Human Cities Ljubljana project. Ljubljana, Urban Planning Institute of the Republic of Slovenia.

Internet 1: www.citizenshandbook.org (accessed: 4 Oct. 2020).

Internet 2: https://www.zagreb.hr/statut-grada-zagreba/110 (accessed 5 Sept. 2020).

Internet 3: http://prostoroz.org/portfolio/items/park-tabor/ (accessed 1 Sept. 2020).

Jaakson, R. (2000) Supra-national spatial planning of the Baltic Sea region and competing narratives for tourism. European Planning Studies, 8, pp. 565-579. DOI: 10.1080/713666424

Koželj, J. (2009) Poudarki in vizije dolgoročnega razvoja Ljubljane do leta 2025. AB Arhitektov bilten, 39(181/182), pp. 4-6.

Kvac, B., Peterlin, M. \& Vrbica, S. (2015) Dobre prakse vključevanja javnosti na področju varstva okolja in urejanja prostora. Ljubljana, PIC.

Nikšič, M. (2014) Access to quality open public space as an urban sustainability measure. In: Bokor, L., Munkacsy, B. and Nikšič, M. (eds.) Locality and (un)sustainable settlements, pp. 284-303. Shrewsbury, Frugeo Geography Research Initiative.

Nikšič, M. (2018) Participatory revitalisation of urban public open space: Urban planners' skills needed for improvement of urban public spaces in participatory manner. In: Novaković, N., Grom, J. P. \& Fikfak, A. (eds.) Realms of urban design: Mapping sustainability, pp. 197-215. Delft, TU Delft Open.
Nikšič, M., Goršič, N. \& Tominc, B. (2018) Tools for participatory provision of urban public spaces: Human cities experience. In: Nikšič, M., Goršič, N., Tominc, B., Selloni, D, Galluzzo, L., Fassi, D., et al. (eds.) Human cities: Challenging the city scale 2014-2018: Investigation, pp. 7-23. Saint-Etienne, France, Cite du Design.

Nikšič, M. \& Sezer, C. (2017) Public space and urban justice. Built Environment, 43(2), pp. 165-172. DOI: 10.2148/benv.43.2.165

Offe, C. (1997) Microaspects of democratic theory: What makes for the deliberative competence of citizens? In: Hadenius, A. (ed.) Democracy's Victory and Crisis, pp. 81-104. Cambridge, Cambridge University Press. DOI: $10.1017 / C B O 9780511558832.005$

Patti, D. \& Polyak, L. (eds.) (2017) Funding the cooperative city. Vienna, Cooperative City Books.

Reason, P. \& Bradbury, H. (eds.) (2001) Handbook of action research: Participative inquiry and practice. London, Sage.

Rešetar, V. (2009) Local committee: Representative of citizens or local political elites. Croatian Public Administration, 9(3), pp. 773-796.

Richards, L. \& Dalbey, M. (2006) Creating great places: The critical role of citizen participation. Community Development: The Journal of the Community Development Society, 37(4), pp. 18-32. DOI: 10.1080/15575330609490193

Ritchie, J. \& Lewis, J. (2003) Qualitative research practice. A guide for social science students and researchers. London, Sage Publications.

Silver, H., Scott, A. \& Kazepov, Y. (2010) Participation in urban contention and deliberation. International Journal of Urban and Regional Research, 34(3), pp. 453-477. DOI: 10.1111/j.1468-2427.2010.00963.x

Svirčić Gotovac, A. \& Kerbler, B. (2019) From post-socialist to sustainable: The city of Ljubljana. Sustainability, 11(126), pp. 1-16. DOI: $10.3390 /$ su11247126

Svirčić Gotovac, A. \& Zlatar Gamberožić, J. (2020) Defense of public spaces in the cases of "We are keeping our park" and "Bring back the magnolia" initiatives in Zagreb. Sociology and Space, 58(1), pp. 5-31.

Sýkora, L. \& Stanilov, K. (2014) The challenge of postsocialist suburbanization. In Stanilov, K. \& Sýkora, L. (eds.) Confronting suburbanization: Urban decentralization in postsocialist central and eastern Europe, pp. 1-33. Chichester, UK, John Wiley \& Sons, Ltd.

DOI: 10.1002/9781118295861.ch1

Toš, I. (ed.) (2012) Participacija u procesima razvoja izgrađene okoline: izvještaj o terenskom istraživanju. Zagreb, Filozofski fakultet Sveučilišta, Katedra za antropologiju.

UNECE (1998) Convention on access to information, public participation in decision-making and access to justice in environmental matters. Aarhus, United Nations Economic Commission for Europe.

Walzer, N. (2010) CDS at 40: The past leading to the future. Community development. Journal of the Community Development Society, 41(4), pp. 401-404. DOI: 10.1080/15575330.2010.532680

Yin, R. (2003) Case study research, design and methods. Thousand Oaks, CA, Sage.

Zakon o prostornom uređenju. Narodne novine, nos. 153/13, 65/17, 114/18, 39/19, 98/19. Zagreb.

Zakon o urejanju prostora. Uradni list Republike Slovenije, no. 61/2017. Ljubljana.

Zlatar Gamberožić, J. (2019) Revitalization paths of urban centers: tentative observational comparison of two cities: Ljubljana and Zagreb. Družboslovne Razprave, 35(90), pp. 83-104.

Žugaj, M., Dumičić, K. \& Dušak, V. (2006) Temelji znanstvenoistraživačkog rada: metodologija i metodika. Varaždin, TIVA. 